\title{
PANAMA AT THE CROSSROADS
}





\section{PANAMA \\ AT THE CROSSROADS}

Economic Development and Political Change in the Twentieth Century

ANDREW ZIMBALIST AND JOHN WEEKS 
University of California Press

Berkeley and Los Angeles, California

University of California Press, Ltd.

Oxford, England

(C) 1991 by

The Regents of the University of California

Library of Congress Cataloging-in-Publication Data

Zimbalist, Andrew S.

Panama at the crossroads : economic development and political change in the twentieth century / Andrew Zimbalist and John Weeks.

p. $\mathrm{cm}$.

Includes bibliographical references and index.

ISBN 0-520-07311-8 (alk. paper)

1. Panama-Economic conditions. 2. Panama-Politics and government. I. Weeks, John. II. Title.

HC147.Z44 1991

338.97287'009'04-dc20

Printed in the United States of America

$\begin{array}{lllllllll}\text { I } & 2 & 3 & 4 & 5 & 6 & 7 & 8 & 9\end{array}$

The paper used in this publication meets the minimum requirements of American National Standard for Information Sciences-Permanence of Paper for Printed Library Materials, ANSI Z39.48-1984. (6) 
To our fathers,

Samuel Zimbalist

and

Alden Weeks 
